\title{
Incidence and Distribution of Viruses Infecting Maize (Zea Mays L.) In South-Western Nigeria
}

\author{
Fajinmi AA ${ }^{1 *}$, Bamiteko $\mathrm{M}^{1}$, Adeniji $\mathrm{OT}^{1}$ and Fajinmi $\mathrm{OB}^{2}$ \\ ${ }^{1}$ Department of Crop Science and Horticulture, Federal University, Nigeria \\ ${ }^{2}$ National Horticultural Research Institute and Training Idi-Isin, Nigeria
}

Submission: May 16, 2019; Published: August 07, 2019

"Corresponding author: Fajinmi AA, Department of Crop Science and Horticulture, Faculty of Agriculture, Federal University, Oye Ekiti, P.M.B. 374, Ikole, Ekiti State, Nigeria

\begin{abstract}
Maize yield has greatly reduced in cultivated fields in many parts of south western Nigeria due to disease infection which has contributed immensely to the cost of production and economic loss to the farmers. A survey was conducted to investigate the incidence, distribution and severity of viral diseases on randomly selected farmer's cultivated maize field. Identification of the diseases was based on visual symptoms. Viral diseases incidence found on maize in the various farms was measured by calculating the percentage of plants showing viral disease symptoms in the maize population while the severity was assessed using a severity index scale of 1-5. Information recorded include the names of towns or villages in which survey was carried out, the coordinates of the farm (location) using the GPS (Global Positioning System), cropping system and other agronomic practices. Results were analyzed by one-way analysis of variance (ANOVA) using the statistical package for social sciences (SPSS) version 16.0. Means were separated where significant difference occur at $p \leq 0.05$. A simple regression analysis was used to test the effect of insect infestation on the severity of maize disease in the study area.

The survey revealed that severity and incidence varied per location. Visible symptoms observed include; chlorotic patches, severe streaking, red pigments and venation along mid rib and vein and stunted growth. The incidence of the maize virus disease ranged between $10-37 \%$ while disease severity in the study area ranged between $3.25 \& 1.50$ in the entire farm surveyed. It was observed that cropping pattern had a positive correlation with disease incidence. Insect infestation in the study area ranged between 1.25-3.50. There was a positive correlation between disease severity and insect infestation, the higher the insect infestation, the higher the severity of the disease. There were variations in the insect incidence and disease severity in all the farm surveyed. Further research will provide a basis for high incidence of pest in cropping systems in the tropics. It is a thing to note that agricultural systems are designed to alter a given ecosystem. It is suggested that adequate crop protection practice should be applied in any cropping system.
\end{abstract}

Keywords: Distribution; Incidence; Streak; Symptoms; Severity

\section{Introduction}

In Nigeria it is known that there is a serious outbreak of streak, rust and leaf spot on maize [1]. Recently the yields of maize on farms have greatly reduced due to disease infection which in turn affects the cost of production and the returns accrual to the farmers [2]. The fact remains that if the disease outbreak goes beyond economic threshold, yield of maize will be reduced thereby threatening food security in the nation. Therefore, it is considered that it is necessary to have information on the type of diseases and the extent of the outbreak at least in the states covered. Ekiti state is one of the maize growing states in south western Nigeria. Agriculture is the main occupation which provides income and employment for more than $75 \%$ of the population of the State. All as a result of the conducive climatic condition, the state enjoys luxuriant vegetation but comes with a range of diseases that is associated which each type of crop.
Table 1: Maize production data in Nigeria (2008-2016).

\begin{tabular}{|c|c|c|c|}
\hline Year & Production & $\begin{array}{c}\text { Unit of } \\
\text { Measure }\end{array}$ & $\begin{array}{c}\text { Growth } \\
\text { Rate }\end{array}$ \\
\hline 2008 & 7970 & $(1000 \mathrm{MT})$ & $22.62 \%$ \\
\hline 2009 & 8950 & $(1000 \mathrm{MT})$ & $12.30 \%$ \\
\hline 2010 & 8800 & $(1000 \mathrm{MT})$ & $-1.68 \%$ \\
\hline 2011 & 9250 & $(1000 \mathrm{MT})$ & $5.11 \%$ \\
\hline 2012 & 7630 & $(1000 \mathrm{MT})$ & $-17.51 \%$ \\
\hline 2013 & 7700 & $(1000 \mathrm{MT})$ & $0.92 \%$ \\
\hline 2014 & 7515 & $(1000 \mathrm{MT})$ & $-2.40 \%$ \\
\hline 2015 & 7000 & $(1000 \mathrm{MT})$ & $-6.85 \%$ \\
\hline 2016 & 7200 & $(1000 \mathrm{MT})$ & $2.86 \%$ \\
\hline
\end{tabular}

MT- Metric ton; Source: United State department of Agriculture 
The incidences of viral diseases cause great yield loss in maize production in Nigeria and the genetic variance in cultivars [3]. The presence and spread are directly or indirectly affected by various factors (environment and weather condition, insect infestation, and other mechanical factors). Maize production in Nigeria has been on the decrease since 2008 [4] (Table 1). It is observed that yield in maize have greatly reduced due to disease infection which in turn affects the cost of production and the returns accruable to the farmers [2].

There is need to have information on the viruses infecting maize, the type of virus, the causative agent, its strains, life cycle which will prompt action on the control and preventive measures for better productivity for farmers. Therefore, it is important to undertake a study that will: ascertain incidence and distribution of the viruses, evaluate incidence, distribution and severity of virus diseases, characterize visible symptoms of maize viruses on farmers' field in the study area.

\section{Materials and Methods}

The research was carried out in the south western part of Nigeria using Ekiti state (Figure 1) as case study. Ekiti, comprising of 16 local government area (LGA) (Figure 2), is in the derived savannah region of Nigeria within Longitudes $4^{\circ} 45^{\prime}-5^{\circ} 45^{\prime}$ East and Latitudes $7^{\circ} 15^{\prime}-8^{\circ} 51^{\prime}$ North which covers $7000 \mathrm{~km}^{2}$ in area. It has an average annual rainfall of about $2000-2700 \mathrm{~mm}$ and the average temperature ranges between $25^{\circ} \mathrm{C}-36^{\circ} \mathrm{C}$. With this background information, a survey was conducted to detect virus disease incidence on cultivated maize crop and evaluate the rate of disease damage.

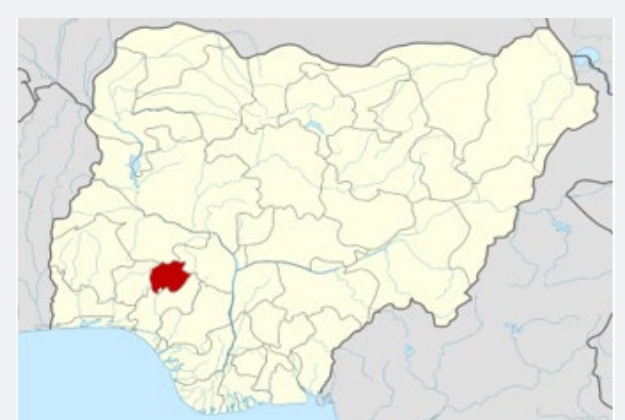

Figure 1: Map of Nigeria showing ekiti state.

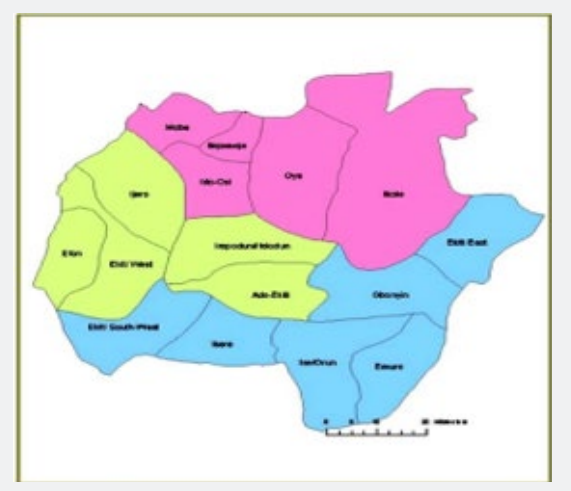

Figure 2: Ekiti State 16 local government areas.

\section{Sampling techniques and data collection}

Maize fields were randomly surveyed, not minding the varieties planted, for the presence of viral symptoms such as streaks, stunting, venation, mosaics. Identification of the diseases was based on visual symptoms [5]. Four farmer's fields with an average size of 100 metres by 100 metres were surveyed per local government area. The sampling was done on hundred randomly selected plants. This was achieved by walking across a ' $W$ ' shaped path in a field with plants spaced at equal distance from each other. Information recorded include the names of towns or villages in which survey was carried out, the coordinates of the farm (location) using the GPS (Global Positioning System), other crops planted on the maize field (in cases of inter-crop farming), crop age, cultural practices, seed source, symptoms observed on the plants, size of the farm. Insect infestation was monitored per maize plant by insect count and identification. Percentage infestation was calculated using the ratio of infested plant and the severity of infestation was measured using a scale of 1 to 4 : 1 - low, 2-average, 3-high and 4-very high. The use of insecticide was recorded as either 'YES or NO'. The incidence of the diseases found on maize in the various farms was measured by using the formula:

$$
\text { Percentage incidence }=\frac{\text { Number of plants showing viral disease symptoms }}{\text { Total number of plants on field }} \times 100
$$

\section{Disease severity evaluation}

Using the severity index scale of [6].

a) Highly resistant, no symptoms or $10 \%$ chlorotic streak on leaves;

b) Resistant with $20 \%$ chlorotic streaks on older leaves;

c) Moderately resistant, $50 \%$ streaking on young leaves and slight stunting;

d) Susceptible, severe streaking on about $75 \%$ of leaf area and stunted plants;

e) Highly susceptible, severe streaking on about $80 \%$ of leaf area, severely stunted and $100 \%$ streaking of dead plants.

\section{Data analysis}

Results collected on insect infestation, percentage incidence and severity were analyzed by one-way analysis of variance (ANOVA) using the statistical package for social sciences (SPSS) version 16.0. Means were separated where significant difference occur at $\mathrm{p} \leq 0.05$. A simple regression analysis was used to test the effect of insect infestation on the severity of maize disease in the study area.

\section{Results}

The symptoms that were observed during the survey varied per location. Visible symptoms observed include; chlorotic patches, severe streaking, red pigment venation along mid rib and vein, stunted growth was also observed (Figure $3 \& 4$ ). 
Streaking is a symptom that occurred at a wide range of location and is well distributed among local governments (Figure 5). The average incidence of maize viruses in each local government of Ekiti State ranges between 10-37\% (Figure 6) with the lowest incidence in Irepodun/ Ifelodun local government area, and the highest in Ikole local government area.
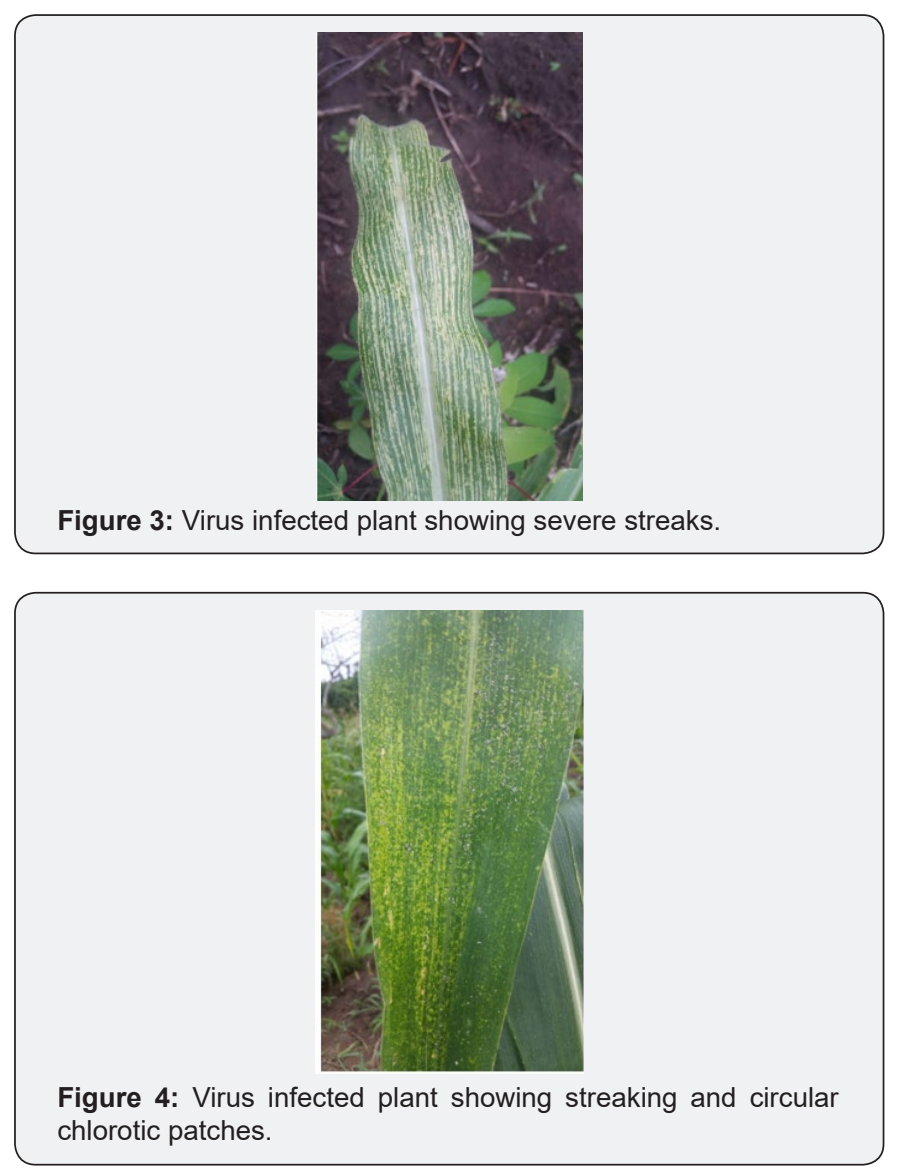

\section{Distribution of maize viruses}

Maize virus was found present in all the farm surveyed, although with varying degree of incidence and severity. (Figure 5, 7 \& Table 2).

\section{Cropping system}

The result showed that inter-cropping pattern had a relationship with percentage virus disease incidence. On Farm planted with maize only (sole), an average of $16 \%$ viral disease incidence was observed compared with maize farm intercropped with cassava, plantain, tomato and or pepper, with an average of $70 \%$ disease incidence (Figure 8). Figure 7 shows the cropping patterns at different location in area surveyed.

\section{Mean separation of insect infestation, disease incidence and severity on maize fields}

The insect pests observed on the maize plants were aphids and leaf hoppers. The result for insect infestation, percentage incidence and disease severity are recorded in Table 2 which shows that infestation in the study area ranged between 1.25 -
3.50 with the lowest insect infestation in maize planted in Emure $(1.25 \pm 0.25)$ LGA and highest recorded in Ilejemeje $(3.50 \pm 0.29)$ LGA. Other LGAs recorded values for insect infestation are intermediate to the two extremes. Disease incidence in the study area ranged between $7.75-37.50$ with the lowest being recorded in Irepodun/Ifelodun $(7.75 \pm 2.25)$ and highest recorded in Ikole

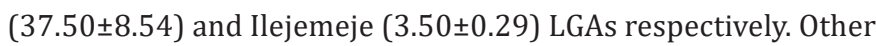
LGAs recorded values for incidence are intermediate to the two extremes. Disease severity in the study area ranged between 3.25 and 1.50 with the lowest being recorded in Irepodun / Ifelodun $(1.50 \pm 0.29)$ and Ekiti South West $(1.50 \pm 0.29)$ respectively while the highest was recorded in Ilejemeje $(3.25 \pm 0.75)$ and Ido/Osi (3.25 \pm 0.75$)$.

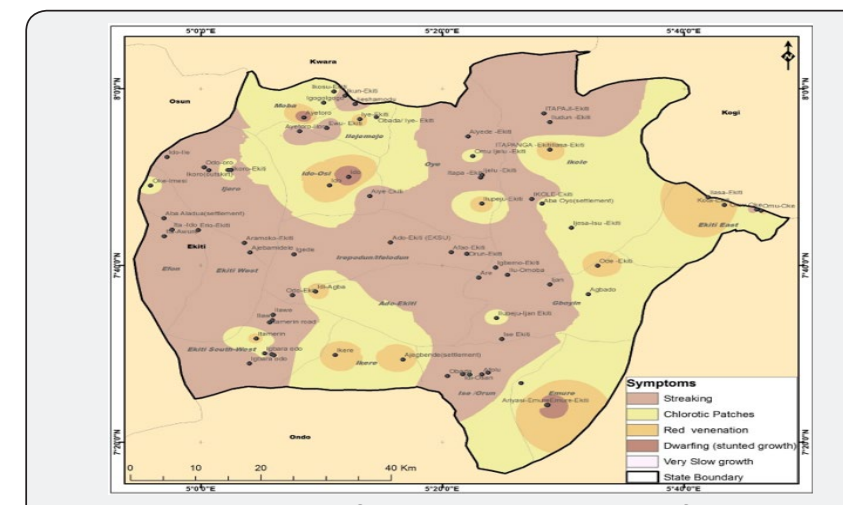

Figure 5: Distribution of viral symptoms on maize field surveyed in ekiti using GPS coordinates.

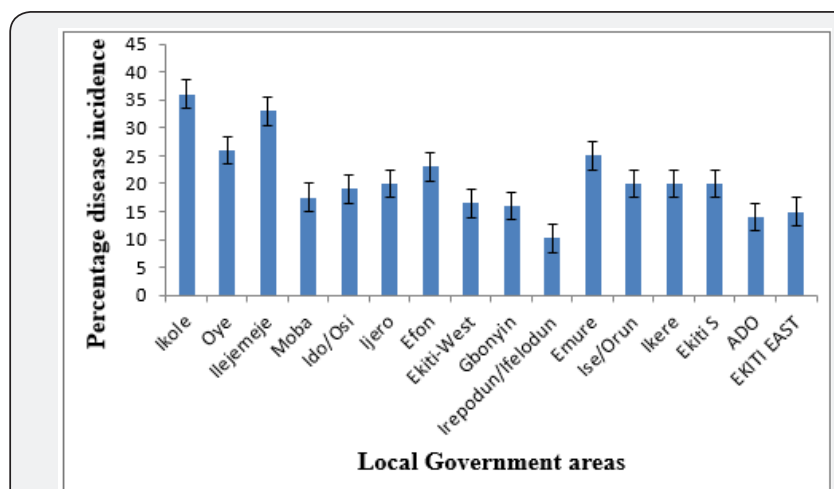

Figure 6: Average disease incidence per local government area.

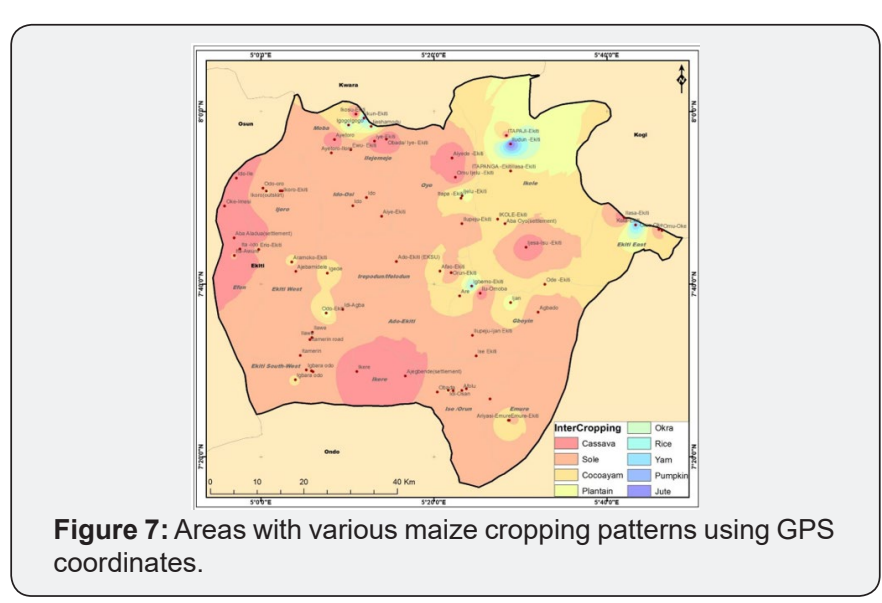




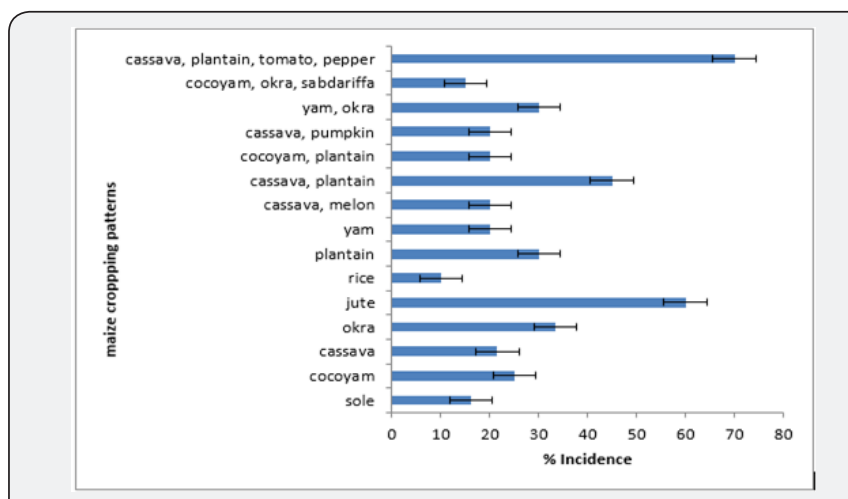

Figure 8: Percentage virus disease incidence in maize cropping patterns.

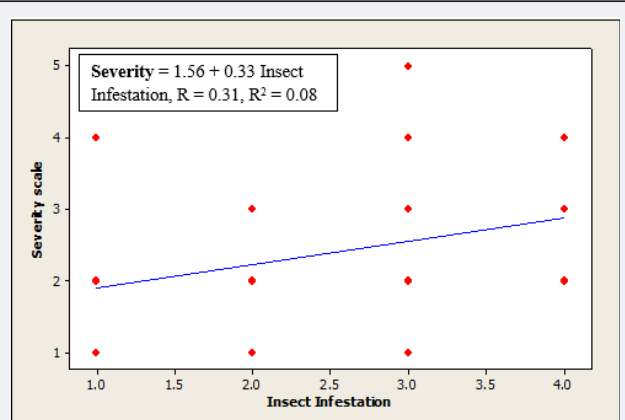

Figure 9: Effects of insect infestation on severity of maize diseases.

\section{Effect of insect infestation on severity of maize viral diseases}

It was observed that severity depends on infestation by $8 \%$. However, the correlation is weak but positive (Figure 9). This implies that, the higher the insect infestation, the higher the severity of the disease. There were variations in the insect incidence and disease severity in all the farm surveyed (Figure 9).

\section{Discussion}

Farmer's response to the presence of viral disease on their maize fields was based on assumption. They could not categorically state or identify the source of viral infection which may be due to lack of information or technical understanding of the problems encountered on their fields [7]. In all farms visited, there were similar opinions among farmers concerning viral disease incidence on cultivated maize fields. The study has shown that the cropping system played a vital role in determining the incidence and severity of viral infection on the maize fields within the state. This has already been observed by [8] that agroecological distribution and cropping system contributed in the viral disease incidence and insects vector dynamics in cultivated fields.

The high incidence of maize virus disease in some maize fields surveyed in some local governments such as Ikole and Ilejemeje, may not have been said not to be connected with the thicker agro-ecological vegetation and favourable environmental condition that favoured wider alternative host range for the virus and the insect vectors which may have made a significant contribution to disease establishment spread [8]. [9] earlier observed a similar pattern of occurrence of cutworm, Agrotis ipsilon (Rott.), armyworm, Mythimna separata (WLK), earworm, Heliothis armigera ( $\mathrm{Hb}$.) and the corn aphid Rhopalosiphum maidis (Fitch.) on three cultivar of maize, based on seasonal and ecological variations and the order of preference for the four pests, respectively. The incidence of virus disease in maize cropping patterns was probably due to the presence of many alternative insects' vectors that facilitated easy spread and infestation of maize plants $[10,11]$ stated that, corn aphid is the most common aphid species on maize and can affect any crop stage. There high numbers can cause plants to turn yellow and cause increase in disease incidence.

Table 2: Insect infestation, incidence and severity of maize viral diseases in the 16-local government.

\begin{tabular}{|c|c|c|c|}
\hline Local Government Area & Insect Infestation & Incidence (\%) & Severity \\
\hline Ado & $3.25 \pm 0.25 \mathrm{~b}$ & $15.00 \pm 5.00 \mathrm{ab}$ & $3.00 \pm 0.41 \mathrm{bc}$ \\
\hline Efon & $2.75 \pm 0.25 \mathrm{~b}$ & $25.00 \pm 8.66 \mathrm{ab}$ & $3.00 \pm 0.41 \mathrm{bc}$ \\
\hline Ekiti East & $2.50 \pm 0.65 \mathrm{ab}$ & $15.00 \pm 6.12 \mathrm{ab}$ & $1.50 \pm 0.29 \mathrm{a}$ \\
\hline Ekiti South West & $2.50 \pm 0.29 \mathrm{ab}$ & $20.00 \pm 0.00 \mathrm{ab}$ & $2.25 \pm 0.25 \mathrm{abc}$ \\
\hline Ekiti West & $2.25 \pm 0.25 \mathrm{ab}$ & $16.50 \pm 6.03 \mathrm{ab}$ & $1.75 \pm 0.25 \mathrm{ab}$ \\
\hline Emure & $1.25 \pm 0.25 \mathrm{a}$ & $25.00 \pm 6.45 \mathrm{ab}$ & $2.25 \pm 0.25 \mathrm{abc}$ \\
\hline Gbonyin & $3.00 \pm 0.57 \mathrm{~b}$ & $17.50 \pm 4.79 \mathrm{ab}$ & $3.25 \pm 0.75 \mathrm{bc}$ \\
\hline Ido/Osi & $2.25 \pm 0.75 \mathrm{ab}$ & $21.25 \pm 1.25 \mathrm{ab}$ & $2.50 \pm 0.50 \mathrm{abc}$ \\
\hline Ijero & $3.00 \pm 0.41 \mathrm{~b}$ & $20.00 \pm 4.08 \mathrm{ab}$ & $2.50 \pm 0.50 \mathrm{abc}$ \\
\hline Ikere & $2.50 \pm 0.29 \mathrm{ab}$ & $20.00 \pm 4.08 \mathrm{ab}$ & $2.50 \pm 0.50 \mathrm{abc}$ \\
\hline Ikole & $2.50 \pm 0.29 \mathrm{ab}$ & $37.50 \pm 8.54 \mathrm{~b}$ & $3.25 \pm 0.25 \mathrm{bc}$ \\
\hline Ilejemeje & $3.50 \pm 0.29 \mathrm{~b}$ & $37.50 \pm 16.01 \mathrm{~b}$ & $1.50 \pm 0.29 \mathrm{a}$ \\
\hline Irepodun/Ifelodun & $2.50 \pm 0.65 \mathrm{ab}$ & $7.75 \pm 2.25 \mathrm{a}$ & $1.75 \pm 0.48 \mathrm{ab}$ \\
\hline
\end{tabular}




\begin{tabular}{|c|c|c|c|}
\hline Moba & $2.25 \pm 0.50 \mathrm{ab}$ & $17.50 \pm 4.79 \mathrm{ab}$ & $2.25 \pm 0.25 \mathrm{abc}$ \\
\hline Oye & $2.75 \pm 0.25 \mathrm{~b}$ & $32.50 \pm 16.52 \mathrm{ab}$ & $2.25 \pm 0.25 \mathrm{abc}$ \\
\hline
\end{tabular}

Mean \pm S.E with Different Superscripts Across Row Are Significantly Different From Each Other (P $\leq 0.05)$.

The tall maize plant inter-cropped with dwarf companion crops would have served as trap crop for insect vectors carrying pathogenic viruses [7]. Thereby causing increase in disease incidence on the maize crop [10], the vectors carrying the virus would have deposited the viral pathogen on the maize plant in a persistent or non-persistent way and not on the dwarf companion crop. This may be the reason why maize inter-cropped with tomato and or pepper had high viral disease incidence. From the result of this study, there was a positive correlation between insect infestations on disease severity which indicates that as insect infestation increases severity also increases. There is a relationship between the insect infestation on the field and severity of disease $[7,12]$. However, the ecological zone, farmer's cultivation practices as well as the cultivar are probable contributors to disease infection, severity and spread [13-42].

\section{Conclusion}

Viruses cause many important plant diseases and are responsible for huge losses in crop production and quality. This study provides information on the incidence of viruses infecting maize and their distribution in maize cropping pattern. Also, it proves that maize cropping pattern with other crops makes it more vulnerable to higher disease incidence and severity as insect infestation increase.

\section{References}

1. Iken JE, Amusa NA (2004) Maize research and production in Nigeria, African Journal of Biotechnology 3(6): 302-307.

2. Fayenuwo JO, Olakojo SA, Akande M, Amusa NA, Olujimi OA (2007) Comparative evaluation of vertebrate pest damage on some newly developed quality protein maize (QPM) varieties in south-western Nigeria. African Journal of Agricultural Research 2(11): 592-595.

3. Salami AE, Adegoke SAO, Adebgite OA (2007) Genetic variability: Among maize cultivars grown in Ekiti -State, Nigeria. Middle east journal of scientific Research (2): 9-13.

4. United State Department of Agriculture, USDA (2016) Nigerian corn production. Index Mundi.

5. Centro Internacional de Mejoramiento de Maiz y Trigo (CIMMYT) International Maize and Wheat Improvement Center (2004). Maize disease. A guide for identification. ( $4^{\text {th }}$ edition), Mexico D.F., p. 124.

6. Fajinmi AA, Dokunmu AO, Akheituamen DO, Onanuga KA (2012) Incidence and infection rate of Maize streak virus disease by Cicadulina triangular on maize plants and its distribution from the lowest diseased leaf under tropical conditions. Archives of Phytopathology and Plant Protection 45(13): 1591-1598.

7. Fajinmi AA, Odebode CA (2010) Evaluation of maize/pepper intercropping model in the management of Pepper veinal mottle virus, genus Potyvirus, family Potyviridae, on cultivated pepper (Capsicum annuum L.) in Nigeria. Archives of Phytopathology and Plant Protection 43(15): 1524-1533.

8. Fajinmi AA, Odebode CA, Fajinmi OB (2011) The effect of agroecological zones on the incidence and distribution of aphid vectors of
9. Pepper veinal mottle virus on cultivated pepper (Capsicum annuum L,) in Nigeria. Journal of Central European Agriculture 12(3): 528-542.

10. Karimullah, Mashwani MA, Ahmed S (1992) Insect pests of Maize crop in different localities of Kalam. Sarhad J Agric 8: 513-518.

11. Mashwani MA (1989) Insect pests and their relative abundance on Maize cultivars in Kalam. Food and Agriculture Organization of the United Nations.

12. Falak Naz, Munir Hussain, Faridullah, Mohammad Din (2003) Insects pests of maize and their losses. Asian Journal of Plant Sciences 2(5): 412-414.

13. Akinbode OA, Ogunniyan DJ, Olasoji JO, Ajijola S, Anjorin FB, et al. (2014) Survey of Resurgence of Maize Diseases in South Western and Kwara States of Nigeria. International Journal of Agriculture and Forestry 4(6): 451-458.

14. Anklam E, Gadani F, Heinze P, Pijnenburg H, Eede GVD (2002) Analytical methods for detection and determination of genetically modified organisms in agricultural crops and plant derived food products. Europe Food Res Technology 214(1): 3-26.

15. Asanzi MC (2001) Development and deployment of maize streak resistant varieties: case study of DR Congo. In: Jacqueline d'A Hughes, Babajide O Odu (Eds.), Proceedings of a conference organized by IITA, p. 284.

16. Bock KR, Guthrie EJ, Woods RD (1974) Purification of maize streak virus and its relationship to viruses associated with streak diseases of sugarcane and Panicum maximum Ann. Applied Biology 77: 289-296.

17. Clark MF, Adams AN (1977) Characteristics of the microplate method of enzyme-linked immuno-sorbent assay for the detection of plant viruses. J Gen Virol 34(3): 475-483.

18. Clark MF (1981) Immuno-sorbent assays in plant pathology. Annual Review of Phytopathology 19: 83-106.

19. Chen CC, Tsai JH, Chiu RJ, Chen MJ (1993) Purification, characterizaiton, and serological analysis of maize stripe virus in Taiwan. Plant Disease 77: $367-372$.

20. Dekker EL, Pinner MS, Markham PG, Van-Regenmortel MHV (1988) Characterization of maize streak virus isolates from different plant species by polyclonal and monoclonal antibodies. J General Virology 69: 983-990.

21. Efron YSK, Kim JM, Fajemisin JH, Mareck CY, Tang ZI, et al. (1989) Breeding for resistance to maize streak virus: A multidisciplinary team approach. Plant Breed 103: 1-36.

22. Fajemisin JM (2001) Overview of maize viruses in sub-Saharan Africa Plant Virology in Sub-Saharan Africa. In: Jacqueline dA Hughes, Babajide 0 Odu (Eds), Proceedings of a conference organized by International Institute of Tropical Agriculture, pp. 158-171.

23. Fajemisin JM, Soyinka SA (1976) Maize streak virus diseases in Africa. In: Williams LE Gordon DTG, Nault LR (Eds.), International Maize Virus disease colloquium and workshop, Ohiom Agricultural Research and Development Center, Wooster, US, pp. 52-61.

24. Fajinmi AA (2011) Agro-ecological incidence and severity of Pepper veinal mottle virus, genus Potyvirus, family Potyviridae, on cultivated pepper (Capsicum annuum L.) in Nigeria. Archives of Phytopathology and Plant Protection 44(4): 307-319.

25. Fakorede MAB, Fajemisin JM, Kim SK, Iken JE (1993) Maize improvement in Nigeria. In: MAB Fakorede (Ed), Maize improvements, production and Utilization in Nigeria. pp. 15-39. 
26. Food and Agriculture Organization FAO (2005) Major food and Agricultural commodities and Producers - Comm. The Statistics Division, Economic and social Department. Food and Agricultural Organization of the United Nations, Rome, Italy.

27. Food and Agriculture Organization (2007) Green Beans Integrated Pest Management, an Ecological guide, Training resource text on crop development, major agronomic practices, disease and insect ecology, insect pests, natural enemies and diseases of green beans. FAO InterCountry Program for the Development and Application of Integrated pest Management in Vegetable growing in South and South-East Asia Section II 7-8.

28. Guthrie WD (1989) Breeding for insect resistance in maize. Plant Breed Rev 6: 209-243.

29. Howell SH (1984) Physical structure and genetic organisation of the genome of maize streak virus (Kenyan isolate). Nucleic Acids Res 12(19): 7359-7375.

30. International Institute of Tropical Agriculture, IITA Communication (2009) Maize Crop.

31. International Institute of Tropical Agriculture, IITA (1989) Maize production manual, Ibadan, Nigeria.

32. International Institute of Tropical Agriculture, IITA (1990) Annual Report, Ibadan, Nigeria.

33. Kamal Sharma, Raj Shekhar Misra (2011) Molecular approaches towards analyzing the viruses infecting maize (Zea mays L) Journal of General and Molecular Virology Vol 3(1): 1-17.

34. Kim SK, Efron Y, Buddenhagen IW, Rossel HW, Bjarnason M, et al. (1989) Recent progress on maize streak resistance breeding program at IITA, Ibadan, Oyo, Nigeria.

35. Knoke JK, Anderson RJ, Louie R, Modelen LV, Findley WR (1983) Insect vectors of maize dwarf mosaic virus and maize chlorotic dwarf virus.
In: Gordon DT, Knoke JK, Nault LR, Ritter RM (Eds.), Proc Int'l Maize Virus Disease Calloq and Workshop, pp. 130-138.

36. Lodish H, Berk A, Zipursky SL (2000) Molecular Cell Biology In: WH Freeman (Ed.), Viruses: Structure, Function, and Uses ( $4^{\text {th }}$ edn), New York.

37. Louie R, Redinbaugh MG, Gordon DT, Abt JJ, Anderson RJ (2000) Maize necrotic streak virus, a new maize virus with similarity to species of the family Tombusviridae. Plant Dis 84(10): 1133-1139.

38. Mc Laughlin MR, Barnett OW, Burrows PM, Baum RH (1981) Improved ELISA conditions for detection of plant viruses. J Virol Methods 3(1): 13-25.

39. Miller SA, Martin RR (1988) Molecular diagnosis of plant diseases. Annual Review Phytopathology 26: 409-432.

40. Offei SK (2001) Virus and viral diseases of sub-Saharan Africa: analysis of responses to questionnaires by scientists in sub-Saharan Africa. In: Jacqueline d A Hughes, Babajide O Odu (Eds.), Plant virology in subSaharan Africa. Proceedings of a conference organized by IITA, pp. 128136.

41. Olakojo SA, Iken JE (2001) Yield performance and stability of some improved maize (Zea mays L) varieties. Moor Journal Agricultural Research 2: 21-24.

42. Roder M, Kleiner K, Sachs A, Keil N, Holzhauser T (2013) Detectability between ELISA and PCR may be strongly influenced by potential differences between cultivars. J Agric Food Chem 61(25): 5936-5945.

43. Shepherd DN, Martin DP, Van Der Walt E, Dent K, Varsani A, et al. (2010) Maize streak virus: an old and complex emerging pathogen. Mol Plant Pathol 11(1): 1-12. 